\title{
1. WIDE-APERTURE SEISMIC REFLECTION PROFILES ACROSS THE BARBADOS RIDGE COMPLEX ${ }^{1}$
}

\author{
John W. Ladd, ${ }^{1,2}$ Graham K. Westbrook, ${ }^{3}$ Peter Buhl,,${ }^{1,2}$ and Nathan Bangs ${ }^{2}$
}

\begin{abstract}
Wide-aperture seismic reflection profiles across the Barbados Ridge complex reveal the internal structure of the accretionary wedge as well as its overall geometry. In the north, where the wedge is only $100 \mathrm{~km}$ wide, the oceanic crustal reflection can be imaged westward beneath the entire accretionary wedge to a point where it meets an eastward-dipping reflection from the forearc basement. Farther south, where the wedge is as much as $300 \mathrm{~km}$ wide, the top of oceanic crust can be imaged $100 \mathrm{~km}$ west from the toe of the wedge, separated from the décollement by as much as 1 second of underthrust sediments. In the easternmost $50 \mathrm{~km}$ of the wedge near latitude $14^{\circ} 20^{\prime} \mathrm{N}$, eastward-verging thrusts and folds are imaged above the décollement. An eastward-dipping backthrust is imaged $110 \mathrm{~km}$ west of the toe of the wedge. Farther south at the latitude of Barbados, eastward-verging thrust packets are imaged $100 \mathrm{~km}$ west of the toe of the wedge.

Seismic velocities determined from these profiles and associated expanding spread profiles and sonobuoys indicate low-velocity regions of the wedge separated laterally from higher velocity regions by zones of high lateral velocity gradients. These high-gradient zones correlate with marked changes in the slope cover lying on top of the wedge, changes in the reflection amplitude of the décollement reflection and oceanic crustal reflection, and locations of eastward-dipping back thrusts, suggesting episodic accretion.
\end{abstract}

\section{INTRODUCTION}

The Barbados Ridge accretionary complex, which lies on the convergent margin between the Caribbean Plate and the Atlantic oceanic lithosphere of the North and South American Plates, narrows from $>300 \mathrm{~km}$ width in the south, east of Tobago, to $<100 \mathrm{~km}$ width in the north, east of Barbuda. This change in width reflects the decreasing rate of growth of the complex as sediment thickness decreases with increasing distance from the Orinoco River, which is the primary source of clastic sediments. Local changes in growth are caused by topographic ridges related to fracture zones that block the northward flow of turbidites from the Orinoco. Previous geophysical work has demonstrated that the Barbados Ridge is underlain by consolidated and unconsolidated sediments that are thickest above the subduction trace where Atlantic Ocean crust first comes into contact with crystalline crust of the Caribbean Plate (Westbrook, 1975; Speed, Westbrook, et al., 1984).

Seismic reflection data have previously demonstrated westward-verging thrusting of the accretionary wedge into the forearc basin sediments as well as the mainly eastward vergent system of thrusts developed where the accretionary wedge accretes Atlantic basin sediments above low-angle detachment faults (décollements). These data showed subcretion beneath the wedge by the development of duplexes and long westward-dipping, outof-sequence thrusts (Biju-Duval et al., 1982; Westbrook et al., 1982; Westbrook and Smith, 1983, 1984). These systems of thrusts in the more landward and deeper parts of the accretionary wedge were, however, poorly imaged; and much of the internal structure of the accretionary wedge remained a matter of conjecture.

Consequently, in 1985, three wide-aperture seismic reflection lines were shot across the accretionary prism with the following

\footnotetext{
${ }^{1}$ Moore, J. C., Mascle, A., et al., 1990. Proc. ODP, Sci. Results, 110: College Station, TX (Ocean Drilling Program).

${ }^{2}$ Lamont-Doherty Geological Observatory, Palisades, NY 10964.

3 Department of Geological Sciences, University of Birmingham, PO Box 363, Birmingham B15 2TT, United Kingdom.
}

objectives: (1) to image more clearly the internal structure of the wedge, (2) to define the contact with the underlying ocean crust and island arc platform, and (3) to map the seismic velocity variations within the accretionary wedge. This paper presents seismic sections from the three wide-aperture lines as well as preliminary commentary upon the major features shown in them (see back-pocket foldout). Detailed analyses of the structures and velocity data are published elsewhere (Tiley, 1988; Westbrook et al., 1988) or are in preparation.

\section{METHODS: DATA ACQUISITION AND PROCESSING}

In 1985 the Robert Conrad and the Charles Darwin, working together, collected $1000 \mathrm{~km}$ of wide-aperture, constant-offset seismic reflection data and four expanding-spread profiles. These profiles and their location are shown in the back-pocket foldout. The Conrad towed a 2.5 - $\mathrm{km}$-long, 48-channel streamer and a tapered four-gun array $(2 \times$ 1000 in. $^{3}+466$ in. $^{3}+325$ in. $\left.^{3}\right)$. The Charles Darwin towed a tapered four-gun array $\left(1000+700+466+300\right.$ in. $\left.^{3}\right)$ similar to the Conrad array. In the constant offset configuration, the Darwin followed $2.5 \mathrm{~km}$ behind the trailing end of the Conrad seismic streamer and fired her air guns every $40 \mathrm{~s}$ on Lines 465 and 479 and every $60 \mathrm{~s}$ on Lines 480 and 484. The Conrad fired her gun array on a similar schedule but with a 20or 30-s phase lag relative to the Darwin.

Post-acquisition common depth point (CDP) sorting of the data into 25 -m bins (except for Line 465 , which was sorted into 50 -m bins) produced 24-trace or 16-trace gathers with shot-receiver offsets ranging from $250 \mathrm{~m}$ to $5 \mathrm{~km}$. Semblance as a function of stacking velocity and two-way time was calculated every 100 or $150 \mathrm{~m}$ along the track from 96-trace gathers formed by combining four or six adjacent 24-trace or 16-trace gathers. To improve the velocity analyses from semblance spectra, 7 or 10 adjacent semblance spectra were summed over a $1-\mathrm{km}$ range. The 1-km spacing was chosen as being roughly the separation between ray paths of the largest offset traces at the seabed, distinguishing independently sampled territories. The data were stacked and Lines 479 , 480 , and 484 were migrated. Long-gap predictive deconvolution was applied to Line 484 before migration to attenuate further the water-bottom multiple.

\section{OBSERVATIONS}

\section{Line 465 Reflection Record}

Line 465 crosses the accretionary wedge $74 \mathrm{~km}$ north of the drilling area on DSDP Leg 78A (Biju-Duval, Moore, et al., 
1984) and ODP Leg 110 (Leg 110 Scientific Drilling Party, 1987). It did not cross the drill sites, to avoid the complications of the Tiburon Rise. At the western end of this line, which runs $180 \mathrm{~km}$ eastward from the island arc to the toe of the accretionary prism, there is a deformed forearc basin (between 130 and $180 \mathrm{~km}$ west of the toe of the prism) lying above a wedge of basement that is deforming into a broad anticlinal high; the velocity analysis from an expanding spread seismic profile $132 \mathrm{~km}$ west of the toe shows that the eastward tip of this wedge has an average velocity of $4.7 \mathrm{~km} / \mathrm{s}$ and that the underlying oceanic crust has velocities that rise rapidly from $5.7 \mathrm{~km} / \mathrm{s}$ to $6.8 \mathrm{~km} / \mathrm{s}$ and then increase slowly to $7.2 \mathrm{~km} / \mathrm{s}$ just above Moho at a depth of $25 \mathrm{~km}$. This $4.7 \mathrm{~km} / \mathrm{s}$ wedge may be, in part, an older accretionary wedge or the flank of the island arc.

The top of the igneous oceanic crust can be traced $135 \mathrm{~km}$ westward from the toe of the accretionary prism, where it lies at 8.5 -s two-way traveltime, to a point beneath the basement of the forearc basin, where it is obscured by the seabed multiple reflection at $12.8 \mathrm{~s}$. The westward-dipping oceanic crustal reflection meets the reflection from the eastward-dipping forearc basement at $12 \mathrm{~s}$ reflection time $125 \mathrm{~km}$ west of the toe of the accretionary prism. Most teleseismic earthquakes in the Lesser Antilles at $16^{\circ} \mathrm{N}$ occur west of $60^{\circ} \mathrm{W}$, which is $125 \mathrm{~km}$ from the toe of the prism on Line 465 (Stein et al., 1984; McCann and Ryan, 1984; Byrne et al., 1988). Presumably, greater shear stresses are developed where the crust overlying the subducting oceanic crust is crystalline and there are no sediments lying on top of oceanic crust to act as lubricants. A trough in the oceanic crust between 105 and $120 \mathrm{~km}$ coincides in position with a transform fault, predicted from magnetic anomalies (Westbrook, 1984), that strikes obliquely across the trend of Line 465 .

Depth conversion of Line 465 indicates that the oceanic crust beneath the accretionary wedge dips about $3^{\circ}$ west while the water bottom dips less than $1^{\circ}$ east for the easternmost $50 \mathrm{~km}$ of the wedge. This very gentle taper of the accretionary prism attests to the low shear traction and high pore pressures along the base of the prism (Zhao et al., 1986).

A strong planar reflection seen about $0.6 \mathrm{~s}$ above the top of oceanic crust beneath the toe of the wedge can be followed 70 $\mathrm{km}$ westward to a point where the reflection suddenly ends, suggesting a possible fault that may be faintly resolved dipping westward in the section. Between 40 and $60 \mathrm{~km}$ from the toe of the wedge, this reflection is interrupted beneath a zone of diffraction hyperbolas, which again may be related to a westwarddipping thrust. This strong planar reflection is the décollement that separates the accretionary wedge above from sediments below that are underthrusting the wedge. From 0 to $40 \mathrm{~km}$ the amplitude or intensity of this reflection increases, indicating that the impedance contrasts associated with this reflection are also increasing westward until they suddenly decrease beneath the zone of diffraction hyperbolas.

The changes in impedance contrast may be related to variations in compaction above and below the décollement. For the most part, the décollement reflection is produced by a zone of locally low acoustic impedance about $20 \mathrm{~m}$ thick that may be produced by high-pressure fluids transmitted along the décollement (Bangs et al., 1987; Bangs, unpublished data). This is compatible with the evidence from drilling on Legs 78A and 110 for high pore-fluid pressures and fluid flow. Further discussion of the interpretation of this seismic section can be found in Westbrook et a1. (1988).

\section{Line 480 Reflection Record}

Lines 479 and 480 form a continuous line extending $280 \mathrm{~km}$ from the forearc basin across the Barbados Ridge south of the Tiburon Rise, where the accretionary wedge is much wider than in the region of Line 465 (the display on the foldout has a piece missing between Line 479 and Line 480 because the migration algorithm did not properly migrate the ends to the two line segments that were not shot as a continuous line). On this composite line the top of oceanic crust can be traced clearly about 100 $\mathrm{km}$ westward from the toe of the wedge to a point where the reflection from it loses much of its amplitude and becomes obscured by the seabed multiple. Lying on top of oceanic crust beneath the easternmost $60 \mathrm{~km}$ of the wedge is about $1 \mathrm{~s}$ of welllayered sediment that we can follow westward from the Atlantic basin to the east, where there are $2.5 \mathrm{~s}$ of sediment lying above oceanic crust. Faulted and less-continous reflections suggest the presence of this layer of sediments as far west as $100 \mathrm{~km}$ from the toe.

Langseth et al. (1988) tentatively correlated a sediment horizon at $8.4 \mathrm{~s}$ just above the décollement at the toe of the prism with a lower Miocene horizon at DSDP Site 543 (Biju-Duval, Moore, et al., 1984). Drilling at Site 672 just south of Site 543 indicated an incipient shear zone within the lower Miocene section. It appears that lower Miocene and older sediments are currently being thrust beneath the toe of the wedge while younger sediments are being accreted to the toe of the wedge as the series of folds and thrust slices that are clearly resolved in the seaward $50 \mathrm{~km}$ of the accretionary wedge.

These folds are cut by thrusts that sole out at the top of the well-bedded sedimentary section at about $8.5 \mathrm{~s}$. The base of these thrusts defines the level of the décollement. The spacing of the thrusts becomes progressively longer toward the west, indicating that shear stresses at the décollement were lower during their formation and that fluid pressures were correspondingly higher. The unbroken sequence of horizons above the décollement between 40 and $55 \mathrm{~km}$ has been overthrust by a wedge that moved up a ramp diverging from the décollement at $60 \mathrm{~km}$. The tip of this thrust wedge at the seabed is at $36 \mathrm{~km}$.

About $110 \mathrm{~km}$ west of the toe of the prism, an eastward-dipping reflection cuts down through the prism from the seabed toward the western termination of the oceanic crustal reflection. This is probably a backthrust along which the younger prism to the east is overthrusting the older arcward portion of the prism. Sandbox models show the development of backthrusts above the seaward termination of more rigid backstops with the thickest part of the prism forming seaward of the backstop termination (Byrne et al., 1988). The relationships among the backthrust, the topography, and the westward fading and pull-up of the ocean crust reflection suggest that the oceanic crust is being thrust beneath a section of the accretionary prism of greater rigidity and higher seismic velocity than found to the east. Westward from the outcrop of the backthrust, coherent reflections define sediments of up to 1-s thickness in two-way time draped on top of the accretionary prism. This sediment drape is not found farther east, suggesting that the younger section to the east of the backthrust has grown very rapidly and/or that its period of growth was preceded by a period of very slow or no growth. This is typical of the eastern part of the complex (Westbrook, 1982; Westbrook et al., 1984).

A similar downslope limit on sediment drape was observed by Breen (1987) at the intersection of the Timor Trough and the Java Trench, where SeaMarc II side-scan reflection images over the accretionary wedge showed a mottled, actively deforming lower slope and a smooth, sediment-draped upper slope separated by a distinct boundary, indicating a sudden decrease in strain rate across the boundary. Breen suggested several possible mechanisms to explain the observations: (1) an arcward decrease in strain rate could be caused by an arcward increase in strength of the incoming sediments, (2) a hiatus in accretion, or (3) accretion by large jumps in the thrust front. In this last pos- 
sibility the lower wedge slope with no sediment drape would be one large thrust packet. Of these, the last explanation does not appear to apply to the Barbados Ridge complex.

A heat-flow profile (Langseth, Westbrook, Hobart, and Foucher, unpublished data) acquired along this line shows normal heat flow from the seabed east of the deformation front where its value is that which would be expected from crust of Late Cretaceous age. The one exception is in the immediate vicinity of a mud volcano on the ocean floor east of the deformation front near this line where high heat flow is observed (Langseth et al., 1988). Westward from the deformation front for $85 \mathrm{~km}$, the heat flow decreases as the thickness of the wedge increases; but at $110 \mathrm{~km}$, westward from the outcrop of the eastward dipping backthrust, the heat flow returns to values approximately the same as those obtained from the undeformed ocean floor. The decreasing heat flow east of the backthrust shows that this portion of the prism is out at thermal equilibrium, probably as a consequence of its rapid growth and thickening. As this eastern portion of the wedge stabilizes with time behind new material accreted farther east, it will warm as heat is transferred upward from the underlying oceanic plate. The more normal heat flow west of the backthrust suggests that this part of the wedge is older and has thermally equilibrated with the underlying lithosphere; however, there is the possibility that there is a component of heating due to frictional slip on the backthrust.

There is a marked change in the vertical seismic velocity gradients across this backthrust as indicated by semblance calculations - the prism to the east of the backthrust has a vertical velocity gradient less than that observed in sediments eastward of the toe of the prism. West of the backthrust, however, the vertical velocity gradient is greater than observed east of the toe of the wedge (Bangs et al., 1986). The low vertical gradient east of the backthrust may be due to the rapid thickening of this part of the prism that developed faster than the sediments could consolidate in response to the increased load. The higher velocity gradients west of the backthrust together with the thicker sediment drape west of the backthrust again suggest that this part of the prism is older and has experienced more compaction. In the Tobago Trough west of the accretionary prism we again observed low vertical gradients in velocity in the thickly ponded sediments between 5- and 6-s two-way time.

\section{Line 479 Reflection Record}

Farther west, between 200 and $210 \mathrm{~km}$ from the toe of the wedge, there is a topographic rise up to the eastern edge of the forearc basin. Between 210 and $220 \mathrm{~km}$, well-bedded sediments of the forearc basin apparently onlap the westward-dipping western flank of the accretionary prism in normal depositional contact. On the island of Barbados, which lies $110 \mathrm{~km}$ to the south on the eastern edge of the forearc basin, structural relationships seen in the field suggested to Torrini et al. (1985) that the contact between Eocene to Miocene forearc basin sediments and the accretionary prism is a thrust. A westward-dipping reflection at 7-s two-way traveltime suggests that the bathymetric step may be fault-controlled, with the westernmost piece of accretionary prism thrusting eastward over the rest of the prism. This may explain the step in the accretionary wedge that underlies the topographic step and the westward tilting of the forearc basin strata that lies just west of the step. Between 225 and 230 $\mathrm{km}$ a diapir-like feature that appears to emanate from the westernmost tip of the accretionary prism penetrates the overlying forearc basin sediments. A discontinuous reflection at $8.0 \mathrm{~s}, 215$ $\mathrm{km}$ from the toe of the wedge, is the top of a $>6 \mathrm{~km} / \mathrm{s}$ unit, as indicated by a sonobuoy over the region. The accretionary wedge above this horizon has velocities of $>3.5 \mathrm{~km} / \mathrm{s}$ (Tiley, 1988).

\section{Line 484 Reflection Record}

Line 484 crosses the accretionary prism at the latitude of Barbados. Eastward of the prism, $2.5 \mathrm{~s}$ of sediments lie on oceanic crust. Reflections in the bottom $2 \mathrm{~s}$ of this sediment section continue undisturbed for $10 \mathrm{~km}$ westward of the toe of the prism. The uppermost $0.5 \mathrm{~s}$ of sediments is deformed within the toe of the prism, into a gentle anticline (at $6.8 \mathrm{~s}$ two-way traveltime and within $10 \mathrm{~km}$ of the deformation front). A detachment surface must separate the anticline from the underlying planar sedimentary horizons, although some thickening of the wedge has occurred above the gently deformed horizon. About $10 \mathrm{~km}$ west of the toe of the prism, the planar horizons between 7 and $7.5 \mathrm{~s}$ two-way time are terminated by a ramp fault that leads up from a décollement just above $8 \mathrm{~s}$.

From 10 to $90 \mathrm{~km}$ westward from the toe of the prism the section above $8 \mathrm{~s}$ is dominated by westward-dipping reflections. In this interval the strong reflection from the top of oceanic crust dips westward from 9 to $9.5 \mathrm{~s}$. A section of parallel sediment reflections occurs above oceanic crust and beneath the westward-dipping reflections. The westward-dipping reflections are tilted horizons within thrust slices that sole out along a through-going décollement at the top of the parallel reflections. At $65 \mathrm{~km}$ west of the toe of the prism, the strong crustal and underthrust sediment reflections become extremely weak, although they can be traced westward for another $55 \mathrm{~km}$. Here also the décollement cuts down deeper into the underthrust sediments.

Fading of these deep reflections coincides with the appearance of a 0.5-s interval of sediments that drape the prism to the west of this point. A similar relationship of sediment drape and deep reflection strength was seen on Line 480 in the neighborhood of a reflection interpreted to be an east-dipping backthrust. On Line 484 , as on Line 480 , there is an abrupt increase in the vertical velocity gradient just west of this change in reflection strength and pinch-out of sediment drape (Bangs, unpublished data; Tiley, 1988). The thickness of the sediment drape increases westward and in several places-such as between 100 and $110 \mathrm{~km}$ and between 165 and $170 \mathrm{~km}$-one can see that the drape is composed of more than one sequence, the lower sequence being more deformed than the upper sequences. Mud diapirs penetrate the sediment drape at $84,115,137,148,155$, and $172 \mathrm{~km}$. The feature at $172 \mathrm{~km}$ is a beautiful example of a mud volcano intersected by the seismic line just off the axis of intrusion. Between 200 and $215 \mathrm{~km}$, on the eastern flank of the Barbados Ridge uplift (Westbrook et al., 1984), there are slump deposits within the drape sequence.

The island of Barbados lies just south of Line 484 on the Barbados Ridge between 220 and $230 \mathrm{~km}$ from the deformation front. To the west in the Tobago Trough forearc basin, there are over $6 \mathrm{~s}$ of layered sediments. The intensity of deformation decreases westward in the trough. There are two clear unconformities on the western flank of the Barbados Ridge related to phases of deformation and uplift. The anticline at the western end of the section (at $270 \mathrm{~km}$ ) shows the progressive thinning of sediment sequences over its crest as it has grown. This fold also shows flexural slip and detachment between 5.5 and $7.5 \mathrm{~s}$. The deepest reflector imaged at about $7.7 \mathrm{~s}$ is not involved in the fold.

\section{CONCLUSIONS}

For the first time, on Line 465 , the entire boundary of an accretionary prism has been imaged which, therefore, places important constraints on the models of prism development (Davis et al., 1983; Dahlen et a1., 1984; Zhao et a1., 1986; Cloos, 1982). 
The top of the oceanic crust has been imaged where it dips beneath the crystalline crust on the oceanward flank of the island arc. An important determinant of the magnitude and repeat times of large-thrust earthquakes is the down-dip length of the seismogenic thrust zone. In the absence of information about the seaward extent of the island arc or continental platform and of good epicenter locations for thrust earthquakes seaward of the island arc, estimates of this length have often been obtained by extrapolating the seismogenic interface to the seaward toe of the accretionary prism. This extrapolation would be greatly in error for the Barbados Ridge complex (Byrne et al., 1988).

The internal structure of the accretionary prism has been imaged to a greater extent than before, including not only the seaward vergent thrusts and folds within the seaward $50 \mathrm{~km}$ of the prism and the underlying décollment, but also the interior outof-sequence thrusts and backthrusts related to the increasing rigidity of the prism westward. A seaward-dipping surface beneath the forearc basin near the western end of the accretionary wedge is the top of a westward-thickening wedge of material with higher seismic velocities than found in the accretionary wedge but which is itself deforming, as indicated by the uplift and broad anticlinal deformation of the overlying forearc basin sediments. The lateral thickness variations in the sediment drape on the accretionary wedge and the presence within it of sequences with different degrees of deformation indicate an episodic history of deformation and accretion.

\section{ACKNOWLEDGMENTS}

The authors thank Marcus Langseth, Bertrand Pinet, and Gregory Moore for helpful reviews of this manuscript. This work was supported by grant OCE 83-17040 from the National Science Foundation (NSF) and grant GR3/5540 from the Natural Environment Research Council (NERC).

\section{REFERENCES}

Bangs, N., Ladd, J. W., Buhl, P., and Westbrook, G. K., 1986. Seismic velocities from the Barbados Ridge and implications for sediment consolidation and dewatering. Eos, 67:1218.

Bangs, N., and Westbrook, G. K., 1987. Synthetic modeling of the décollement reflector in the northern Barbados Ridge accretionary complex. Eos, 68:1487.

Biju-Duval, B., Le Quellec, P., Mascle, A., Renard, V., and Valery, P., 1982. Multibeam bathymetric survey and high resolution seismic investigations on the Barbados Ridge complex (eastern Caribbean): a key to the knowledge and interpretation of an accretionary wedge. Tectonophysics, 80:275-304.

Biju-Duval, B., Moore, J. C., et al., 1984. Init. Repts. DSDP, 78A, Pt. 1: Washington (U.S. Govt. Printing Office).

Breen, N. A., 1987. Three Investigations of Accretionary Wedge Deformation (Ph.D. dissert.). University of California at Santa Cruz.

Byrne, D. E., Davis, D. M., Sykes, L. R., 1988. Mechanics of the shallow region of subduction zones and the loci and maximum size of thrust earthquakes. Tectonics, 7:833-857.

Cloos, M. L., 1982. Flow melanges: numerical modeling and geologic constraints on their origin in the Franciscan subduction complex, California. Geol. Soc. Am. Bull., 93:330-345.

Dahlen, F. A., Suppe, J., Davis, D. M., 1984. Mechanics of fold-andthrust belts and accretionary wedges: cohesive Coulomb theory. $J$. Geophys. Res., 89:10087-10101.

Davis, D. M., Suppe, J., Dahlen, F. A., 1983. Mechanics of fold-andthrust belts and accretionary wedges, J. Geophys. Res., 88:11531172.
Langseth, M. G., Westbrook, G. K., Hobart, M. A., 1988. Geophysical survey of a mud volcano seaward of the Barbados Ridge accretionary complex. J. Geophys. Res., 93:1049-1062.

Leg 110 Scientific Drilling Party, 1987. Accretionary complex penetrated, defined. Geotimes, 32:13-16.

McCann, W. R., and Ryan, R., 1984. Seismic epicenters from local networks 1977-1981. In Speed, R. C., Westbrook, G. K., et al. (Eds.), Lesser Antilles Arc and Adjacent Terranes. Atlas 10 Ocean Margin Drilling Program, Regional Atlas Series: Woods Hole, MA (Marine Science International), Sheet 13.

Speed. R. C., Westbrook, G. K., Mascle, A., Biju-Duval, B., Ladd, J. W., Saunders, J. B., Stein, S., Schoonmaker, J. E., Moore, J. C., 1984. Lesser Antilles Arc and Adjacent Terranes. Atlas 10, Ocean Margin Drilling Program, Regional Atlas Series: Woods Hole, MA (Marine Science International), 27 sheets.

Stein, S., Engeln, J. F., Wiens, D. A., Speed, R. C., Fujita, K., 1984. Seismicity 1950-1978: epicenter and hypocenter distribution and focal mechanisms. In Speed, R. C., Westbrook, G. K., et al. (Eds.), Lesser Antilles Arc and Adjacent Terranes. Atlas 10, Ocean Margin Drilling Program, Regional Atlas Series: Woods Hole, MA (Marine Science International), Sheet 12.

Tiley, G. J., 1988. A Geophysical Investigation of the Physical Properties of Subduction Accretion Complexes (Ph.D. thesis), University of Birmingham, United Kingdom.

Torrini, R. E., Jr., Speed, R. C., and Mattioli, G. S., 1985. Tectonic relationships between forearc-basin strata and the accretionary complex at Bath, Barbados. Geol. Soc. Am. Buli., 96: 861-874.

Westbrook, G. K., 1975. The structure of the crust and upper mantle in the region of Barbados and the Lesser Antilles. Geophys. J. R. Astron. Soc., 43:201-242.

1982. The Barbados Ridge complex: tectonics of a mature forearc system. In Leggett, J. K. (Ed.), Trench-Forearc Geology: Sedimentation and Tectonics on Modern and Ancient Active Plate Margins. Spec. Publ., Geol. Soc. London, 10:275-290. 1984. Magnetic lineations and fracture zones. In Speed, R. C., Westbrook, G. K., et al. (Eds.), Lesser Antilles Arc and Adjacent Terranes. Atlas 10, Ocean Margin Drilling Program, Regional Atlas Series: Woods Hole, MA (Marine Science International), Sheet 5.

Westbrook, G. K., and Smith, M. J., 1983. Long décollements and mud volcanoes: evidence from the Barbados Ridge complex for the role of high pore-fluid pressures in the development at an accretionary complex. Geology, 11:279-283.

1984. Migrated seismic sections across the outer deformation front of the accretionary prism. In Speed, R. C., Westbrook, G. K., et al. (Eds.), Lesser Antilles Arc and Adjacent Terranes. Atlas 10, Ocean Margin Drilling Program, Regional Atlas Series:Woods Hole, MA (Marine Science International), Sheet 23.

Westbrook, G. K., Smith, M. J., Peacock, J. H., and Poulter, M. J., 1982. Extensive underthrusting of undeformed sediment beneath the accretionary complex of the Lesser Antilles subduction zone. $\mathrm{Na}$ ture, 300:625-628.

Westbrook, G. K., Mascle, A., and Biju-Duval, B., 1984. Geophysics and the structure of the Lesser Antilles forearc. In Biju-Duval, B., Moore, J. C., et al., Init. Repts. DSDP, 78A, Pt. 1: Washington (U.S. Govt. Printing Office), 23-38.

Westbrook, G. K., Ladd, J. W., Buhl, P., Bangs, N., and Tiley, G., 1988. Cross section of an accretionary wedge: Barbados Ridge complex. Geology, 16: 631-635.

Zhao, W. L., Davis, D. M., Dahlen, F. A., and Suppe, J., 1986. Origin of convex accretionary wedges: evidence from Barbados. J. Geophys. Res., 91: 10246-10258.

Date of initial receipt: 23 June 1988

Date of acceptance: 11 April 1989

Ms 110B-168 